\title{
Re-emergence of syphilis in women of reproductive age and its association with the increase in congenital syphilis in Mexico during 2010-2019: an ecological study
}

Santa García-Cisneros, Antonia Herrera-Ortiz, Maria Olamendi-Portugal and Miguel Angel Sánchez-Alemán * (B)

\begin{abstract}
Background: Syphilis is a sexually transmitted infection that is re-emerging in different parts of the world. This infection can be transmitted during pregnancy, causing neonatal syphilis. The objective of this study was to examine trend in syphilis, congenital syphilis, and neonatal deaths among the Mexican population during 2010-2019.

Methods: An ecological study was carried out to collect information about the incidence of syphilis, the incidence of congenital syphilis, and the incidence of neonatal death from congenital syphilis. The variables were described considering age, sex, Mexican state, and year. Trends across time (calendar year) were analyzed using linear regression, increases were estimated with $95 \%$ confidence intervals, and $p<0.05$ was considered statistically significant.

Results: The incidence of syphilis increased by an average of 0.336 cases $/ 100,000$ per year and was higher among women aged 15-19 years (0.693 cases). Cases of congenital syphilis increased from 62 cases in 2010 to 372 cases in 2019; furthermore, the increase in syphilis cases among women aged 20 to 24 years was associated with an increase in cases of congenital syphilis. In 2010, 50\% of Mexican states did not report cases of congenital syphilis, but in 2018, only 10\% did not report cases of congenital syphilis. Between 2010 and 2018, 83 neonatal deaths were reported, with the highest incidence in 2018 (0.88 deaths/100,000 newborns).
\end{abstract}

Conclusion: The incidence of congenital syphilis is increasing in Mexico. As a consequence of the reemergence of syphilis among the population of reproductive age, it is necessary to address and treat syphilis in various population groups.

Keywords: Syphilis, Congenital syphilis, Sexually transmitted diseases, Mexico

*Correspondence: msanchez@insp.mx

Centro de Investigación sobre Enfermedades Infecciosas, Instituto

Nacional de Salud Pública, Cerrada Los Pinos y Caminera, Cuernavaca,

Universidad No. 655 Colonia Santa María Ahuacatitlán, Morelos, México

\section{Background}

Syphilis is a sexually transmitted infection (STI) caused by the bacterium Treponema pallidum subs pallidum. Syphilis has four stages; the primary stage begins with a chancre, which appears on the glans, penis, labia majora, labia minora, perineum, or extragenital regions (palate, anus, rectus, fingers, or tongue) [1]. Secondary syphilis is characterized by systemic bacterial spread, erythematous 


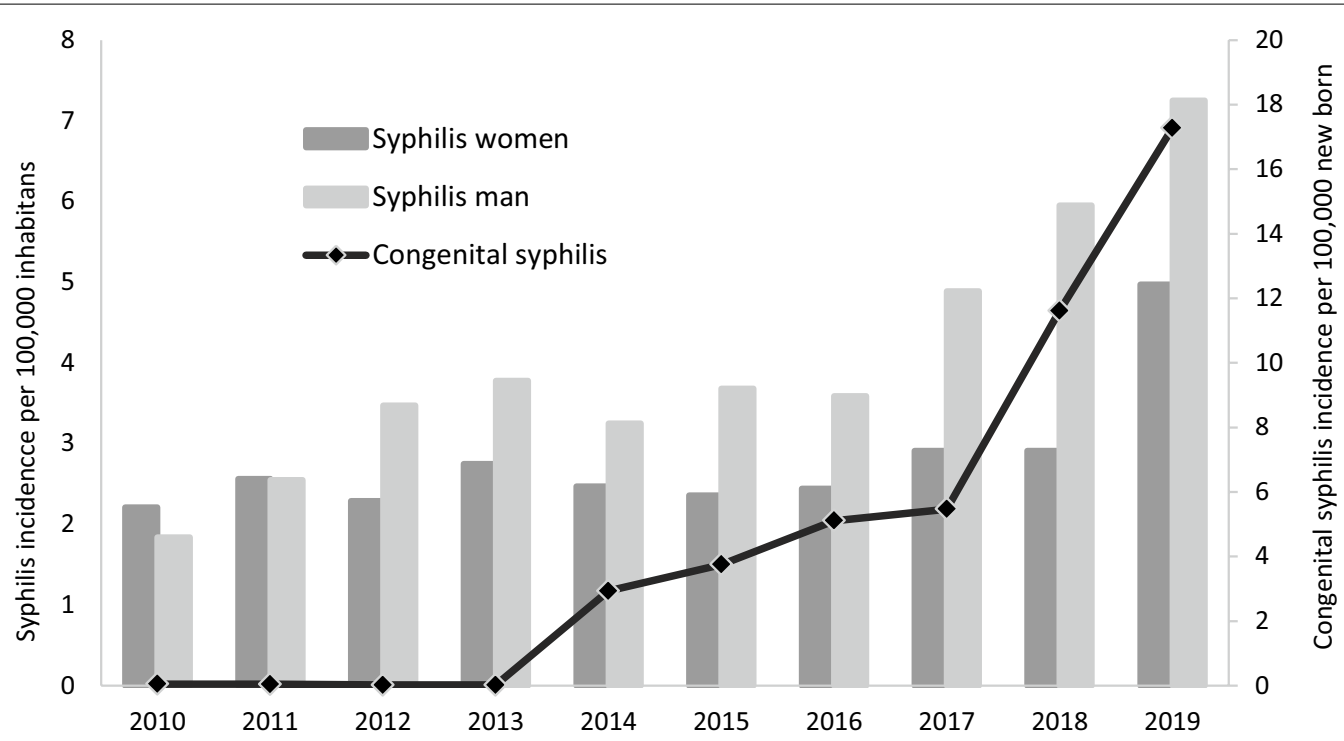

Fig. 1 Syphilis incidence in Mexico, 2010-2019. The bars show the incidence of syphilis in Mexico between 2010 and 2019, stratified by sex. The line shows the incidence of congenital syphilis. In 2010, 2011, 2012 and 2013, the incidence of congenital syphilis was 0.05, 0.04, 0.02 and 0.02, respectively

rashes appearing on palms of hands, soles of feet, chest, and back. Later, there is a latency phase that lacks clinical manifestation, but nontreponemal serological tests remain positive; this stage can last up to 20 years. Infection remains continuous, and the tertiary stage develops, and this stage affects the cardiovascular, nervous, and musculoskeletal systems [1-3]. T. pallidum can cross the placental barrier, causing congenital syphilis. Approximately $50 \%$ of pregnant women infected with $T$. pallidum who are not treated transmit syphilis to their children before birth. In persons living with HIV, the natural history of syphilis is different: there are more patients with tertiary syphilis, patients are diagnosed earlier with Aids, and the presence of syphilis increases the transmission of HIV $[4,5]$.

According to the World Health Organization (WHO), in 2016, the worldwide incidence of curable STIs was estimated to be 376.4 million new cases among people aged 15 to 49 years; of these new cases, 6.3 million were syphilis, resulting in an incidence of 1.5 cases per 1000 inhabitants worldwide and 2.0 cases per 1000 inhabitants in America [6]. Furthermore, syphilis caused 200,000 stillbirths and deaths worldwide, making it one of the leading causes of newborn death. In the Americas, an estimated 22,800 cases of mother-to-child syphilis transmission were estimated, with a rate of 1.7 cases per 1000 live births [7]. In Mexico, an increase in the incidence of syphilis was observed between 2003 and 2013, especially among men aged 20-24 years and 25-44 years [8]. The objective of this study was to determine the trends of syphilis and congenital syphilis in Mexico between 2010 and 2019 through the information available in the General Directorate of Epidemiology of the Ministry of Health of Mexico.

\section{Methods}

An ecological study was carried out to review the information about the incidence of syphilis, the incidence of congenital syphilis, and the number of cases of congenital syphilis from the Morbidity Yearbooks of the General Directorate of Epidemiology of the Ministry of Health of Mexico from 2010 to 2019. No administrative permissions were required to access the data; the information was freely accessible. The information about the incidences of syphilis and congenital syphilis was stratified by age, sex, year, and Mexican state, without any variable that could identify the participants. The number of neonatal deaths was obtained from the Epidemiological and Statistical Overview of Mortality due to Causes Subject to Epidemiological Surveillance in Mexico. From 2010 to 2018 (2019 is not yet available), the number of newborns for all years was obtained from the National Institute of Statistics and Geography of Mexico. In the present study, neonatal death was considered death in children under 1 year of age.

The analysis of the trends in syphilis incidence among women, syphilis incidence among men, congenital syphilis incidence, and syphilis incidence stratified by age group and sex from 2010 to 2019 was evaluated by measuring the average change by linear regression with 


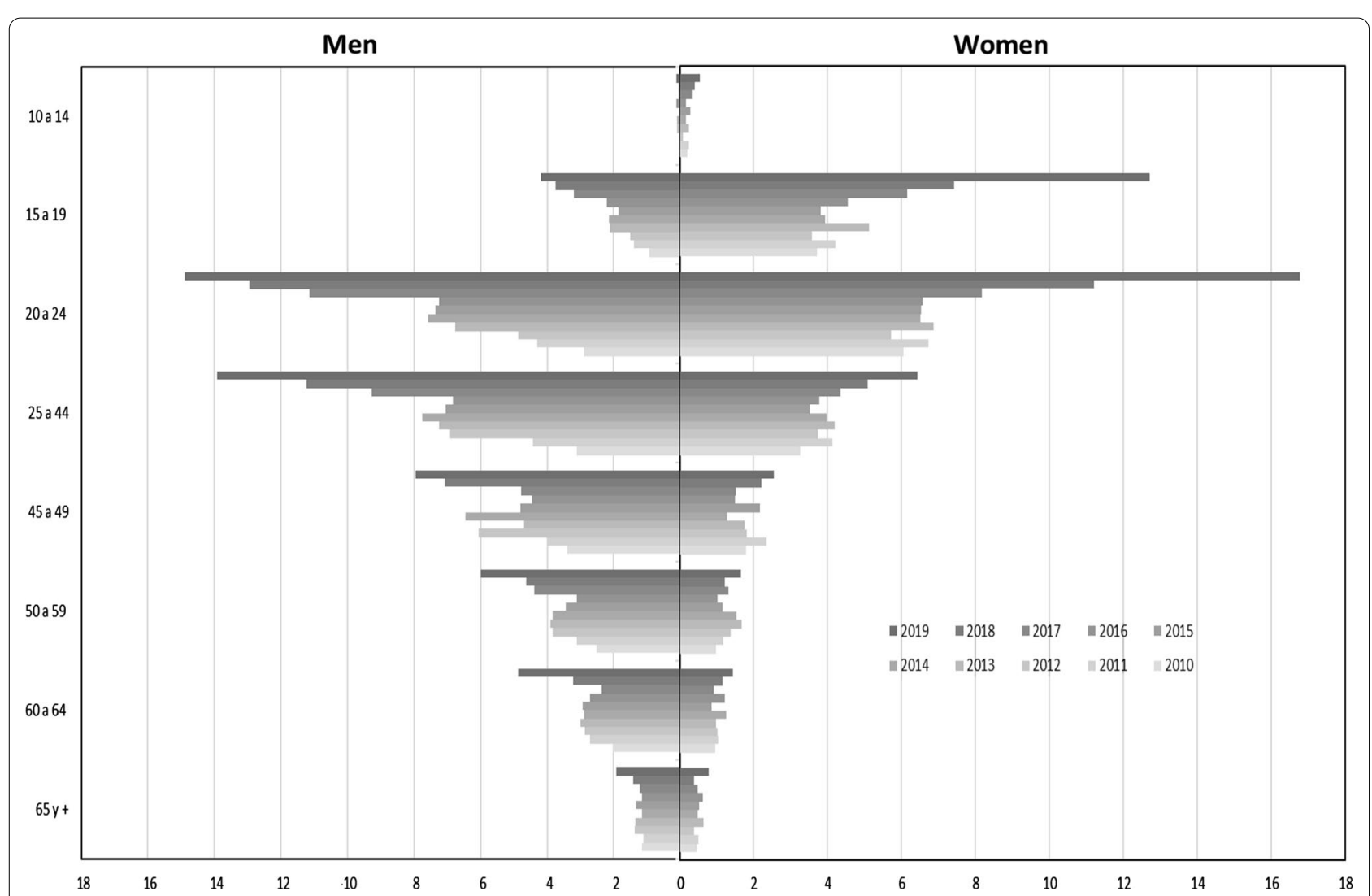

Fig. 2 Syphilis incidence stratified by sex and age, Mexico 2010-2019. The figure shows the change in the incidence of syphilis by age group and sex from 2010 to 2019. The greater the intensity of the color, greater the calendar year

95\% confidence intervals (95\% CI). Linear regression was evaluated with standardized residual plots and R square to determine the curve of best fit (lineal, quadratic or exponential). Finally, comparisons were evaluated with Student's t-test for slopes; $\mathrm{p}<0.05$ was considered statistically significant.

The number of cases of congenital syphilis was stratified into 0 cases, 1 case, 2-4 cases and 5 or more cases, considering the quartiles of the variable. A comparison, with Fisher's test, was made between 2010 and 2019 considering each state of the republic. Subsequently, information on neonatal deaths from congenital syphilis was analyzed from 2010 to 2018, considering the number of cases and the number of newborns from each year to determine mortality.

Finally, the correlation between the trends in cases of congenital syphilis and incidence of syphilis in women aged 15-19 years and 20-24 years as well as the correlation between the incidence of congenital syphilis and the incidence of syphilis among women aged $20-24$ years were evaluated for each state of the republic using the Spearman correlation test. The correlations were considered statistically significant when $\mathrm{p}<0.05$, and all the analyses were carried out with the statistical program GraphPad 10.0.

\section{Results}

The highest incidence of syphilis in the general population was observed in 2019, with 6.09 cases per 100,000 inhabitants, compared to 2.03 cases in 2010 , with an average annual increase of 0.336 cases per 100,000 inhabitants $\left(\mathrm{CI}_{95 \%} 0.180-0.492, \mathrm{p}=0.001, \mathrm{r}^{2}=0.755\right)$. Since 2012, men have had a higher incidence of syphilis than women; the average increase among men was 0.482 cases per 100,000 inhabitants $\left(\mathrm{CI}_{95 \%}\right.$ 0.303-0.660, $\mathrm{p}<0.001$, $\left.\mathrm{r}^{2}=0.829\right)$ compared to the increase among women, which was 0.178 cases per 100,000 inhabitants $\left(\mathrm{CI}_{95 \%}\right.$ 0.017-0.339, $\mathrm{p}=0.034, \mathrm{r}^{2}=0.448$ ). The difference in the increases in male and female incidences was statistically significant $(\mathrm{p}=0.010)$. An increase in congenital syphilis was observed, with a rate of 2.93 per 100,000 newborns in 2014 and up to 17.28 in 2019, with an average annual increase of 1.693 per 100,000 newborns $\left(\mathrm{CI}_{95 \%}\right.$ 0.9862.394, $\mathrm{p}<0.001, \mathrm{r}^{2}=0.794$ ), as shown in Fig. 1 .

Among women, the highest incidence occurred in the 20-24-year-old age group, with 16.77 cases per 100,000 
a. Cases of congenital syphilis by state

\begin{tabular}{|l|r|r|r|r|r|r|r|r|r|r|}
\hline & 2010 & 2011 & 2012 & 2013 & 2014 & 2015 & 2016 & 2017 & 2018 & 2019 \\
\hline Aguascalientes & 0 & 0 & 0 & 0 & 0 & 0 & 3 & 5 & 5 & 16 \\
\hline Baja California & 17 & 20 & 8 & 12 & 15 & 24 & 38 & 30 & 24 & 79 \\
\hline Baja Cal. Sur & 0 & 1 & 0 & 0 & 1 & 1 & 1 & 8 & 3 & 9 \\
\hline Campeche & 1 & 0 & 0 & 0 & 0 & 0 & 0 & 0 & 1 & 0 \\
\hline Cohauila & 0 & 1 & 2 & 0 & 0 & 5 & 7 & 2 & 12 & 11 \\
\hline Colima & 6 & 3 & 1 & 0 & 0 & 0 & 1 & 1 & 3 & 6 \\
\hline Chiapas & 0 & 0 & 0 & 2 & 0 & 0 & 0 & 0 & 0 & 4 \\
\hline Chihuahua & 7 & 6 & 1 & 0 & 4 & 8 & 4 & 1 & 3 & 4 \\
\hline Cd. de México & 0 & 1 & 0 & 0 & 1 & 5 & 4 & 1 & 3 & 3 \\
\hline Durango & 0 & 0 & 0 & 0 & 5 & 4 & 4 & 2 & 4 & 11 \\
\hline Guanajuato & 1 & 1 & 4 & 1 & 1 & 1 & 0 & 3 & 5 & 6 \\
\hline Guerrero & 1 & 0 & 4 & 0 & 1 & 0 & 0 & 0 & 1 & 4 \\
\hline Hidalgo & 2 & 1 & 0 & 0 & 0 & 0 & 0 & 0 & 0 & 2 \\
\hline Jalisco & 3 & 2 & 1 & 3 & 0 & 1 & 0 & 0 & 40 & 57 \\
\hline México & 0 & 3 & 2 & 1 & 0 & 1 & 5 & 3 & 4 & 1 \\
\hline Michoacán & 0 & 0 & 0 & 0 & 0 & 0 & 4 & 1 & 1 & 6 \\
\hline Morelos & 0 & 2 & 0 & 0 & 2 & 0 & 0 & 0 & 1 & 1 \\
\hline Nayarit & 0 & 0 & 2 & 2 & 0 & 1 & 2 & 1 & 5 & 12 \\
\hline Nuevo León & 6 & 10 & 7 & 7 & 2 & 2 & 9 & 10 & 38 & 13 \\
\hline Oaxaca & 1 & 3 & 0 & 0 & 0 & 0 & 0 & 0 & 0 & 0 \\
\hline Puebla & 0 & 1 & 1 & 2 & 0 & 3 & 1 & 2 & 4 & 5 \\
\hline Querétaro & 0 & 1 & 0 & 0 & 1 & 1 & 1 & 5 & 4 & 2 \\
\hline Quintana Roo & 1 & 0 & 0 & 0 & 0 & 0 & 3 & 1 & 3 & 2 \\
\hline San Luis Potosí & 1 & 1 & 1 & 0 & 3 & 1 & 1 & 1 & 2 & 8 \\
\hline Sinaloa & 2 & 4 & 3 & 1 & 4 & 3 & 4 & 2 & 7 & 29 \\
\hline Sonora & 9 & 2 & 8 & 3 & 6 & 16 & 13 & 21 & 44 & 29 \\
\hline Tabasco & 0 & 0 & 1 & 0 & 0 & 0 & 0 & 1 & 6 & 10 \\
\hline Tamaulipas & 0 & 1 & 0 & 1 & 0 & 0 & 1 & 0 & 18 & 20 \\
\hline Tlaxcala & 1 & 0 & 0 & 0 & 2 & 0 & 0 & 1 & 0 & 0 \\
\hline Veracruz & 3 & 3 & 1 & 3 & 2 & 3 & 3 & 11 & 6 & 15 \\
\hline Yucatan & 0 & 0 & 1 & 2 & 13 & 2 & 4 & 5 & 3 & 5 \\
\hline Zacatecas & 0 & 0 & 1 & 3 & 2 & 1 & 0 & 3 & 2 & 2 \\
\hline Total & 62 & 67 & 49 & 43 & 65 & 83 & 113 & 121 & 252 & 372 \\
\hline
\end{tabular}

\section{b. Cases of congenital syphilis, Mexico 2010}
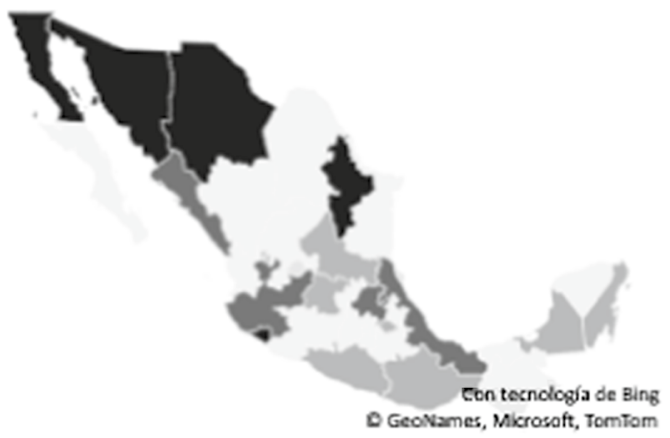

c. Cases of congenital syphilis, Mexico 2019

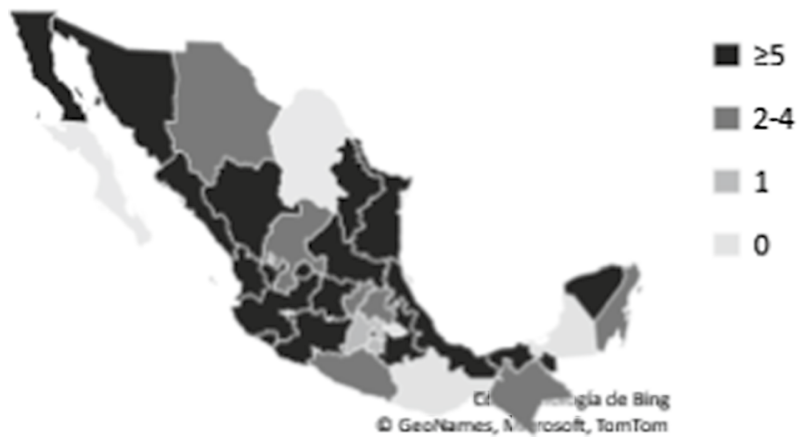

Fig. 3 New cases of congenital syphilis by state, Mexico 2010-2019. a Shows the number of cases of congenital syphilis in each of the 32 Mexican states from 2010 to 2019. The darker colors indicate a greater number of cases. b, c Show the strained cases of congenital syphilis in 2010 and 2019 (with 0 cases, 1 case, 2-4 cases and $\geq 5$ cases, considering the quartiles of the variable). A comparison with Fisher's test, was made between 2010 and 2019. Microsoft product screen shots reprinted with permission from Microsoft Corporation

inhabitants in 2019 and an annual increase of 0.843 per 100,000 inhabitants $\left(\mathrm{CI}_{95 \%} 0.230-1.457 ; \mathrm{p}=0.013\right.$; $\left.\mathrm{r}^{2}=0.557\right)$, followed by the $15-19$-year-old group, with an incidence of 12.7 cases per 100,000 inhabitants in 2019 and an average annual increase of $0.693\left(\mathrm{CI}_{95 \%} 0.191-\right.$ $1.194 ; \mathrm{p}=0.013 ; \mathrm{r}^{2}=0.560$ ). Among men, the increase in incidence was highest in the 20-24-year-old group, with a rate of 14.89 cases per 100,000 inhabitants in 2019 and an annual increase of 1.080 per 100,000 inhabitants $\left(\mathrm{CI}_{95 \%} 0.654-1.505 ; \mathrm{p}<0.001, \mathrm{r}^{2}=0.810\right)$, followed by the 25-44-year-old group, with an incidence of 13.93 cases per 100,000 in 2019 and an annual increase of 0.991 cases per $100,000\left(\mathrm{CI}_{95 \%} 0.462-1.521, \mathrm{p}=0.002, \mathrm{r}^{2}=0.700\right)$, as shown in Fig. 2.

We reported a constant increase in new cases of congenital syphilis, with 62 cases in 2010, 83 cases in 2015, and 372 cases in 2019, demonstrating exponential growth $\left(\mathrm{r}^{2}=0.747, \mathrm{p}=001\right)$. The states with the highest number of congenital syphilis cases in 2010 were Baja California, Colima, Chihuahua, Nuevo León, and Sonora, which reported between 6 and 17 cases, while in 2019, Baja California, Jalisco, Sinaloa, Sonora, and Tamaulipas reported between 20 and 79 cases of congenital syphilis. In addition, of the 32 states of Mexico, 16 did not report congenital syphilis cases in 2010; on the other hand, only three states did not report congenital syphilis cases in 2019, a difference which was statistically significant $(\mathrm{p}<0.001)$. In 2010 , only 5 states had 5 or more cases of congenital syphilis; in 2019, 19 states reported 5 or more cases of congenital syphilis $(\mathrm{p}<0.001)$. The states of Campeche, Hidalgo, Morelos, and Tlaxcala had two or fewer congenital syphilis cases from 2010 to 2019, as shown in Fig. 3.

The number of cases of congenital syphilis was correlated with the incidence of syphilis among women from 2010 to $2019\left(\mathrm{r}^{2}=0.787, \mathrm{p}<0.001\right)$; however, this correlation was higher when stratifying by age. Among women aged 15-19 years, each increase in incidence unit showed an average increase of 36 new cases of congenital syphilis (slope 36.1, $\mathrm{CI}_{95 \%}$ 26.5-45.8, $\mathrm{r}^{2}=0.904 ; \mathrm{p}<0.001$ ); among women aged $20-24$ years, this increase was an 


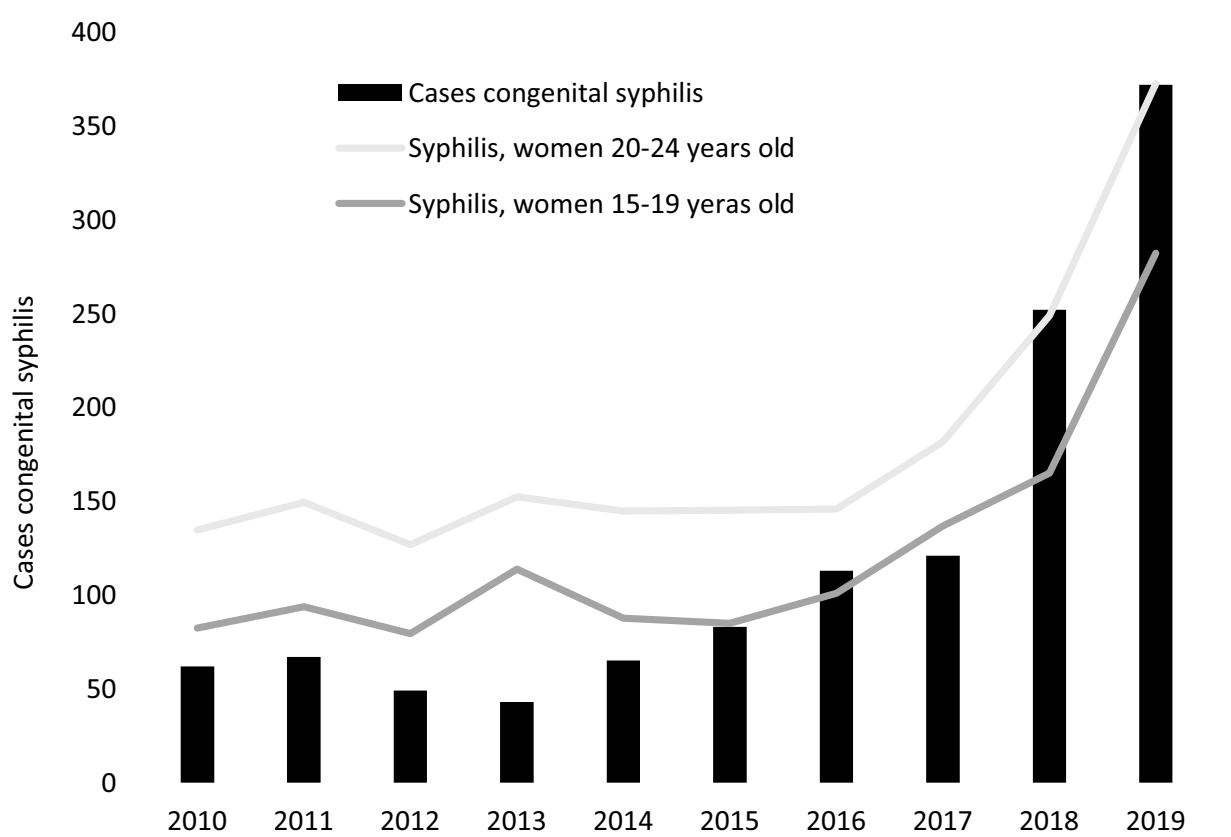

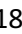

16

14

10

8

6

4

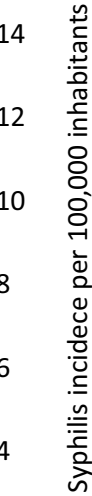

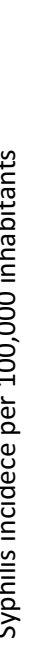

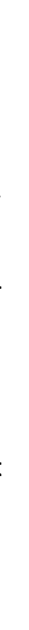

Fig. 4 Syphilis among women aged 15-24 years and congenital syphilis, Mexico 2010-2019. The bars show the number of cases of congenital syphilis. The lines show the incidence of congenital syphilis in women aged 15-19 and 20-24 years, with $r^{2}$ values of 0.904 and 0.958, respectively

average of 30 cases per year (slope $30.4, \mathrm{CI}_{95 \%} 24.8-36.0$, $\left.\mathrm{r}^{2}=0.952 ; \mathrm{p}<0.001\right)$, as shown in Fig. 4. The correlation between syphilis and congenital syphilis by Mexican state was evaluated, and data of women aged 20-24 years from 2019 was used, which demonstrated an $\mathrm{r}^{2}=0.621$; $\mathrm{p}<0.001$. The seven states that reported an incidence of congenital syphilis greater than 40 cases per 100,000 live births were the same states that reported an incidence of syphilis greater than 40 cases per 100,000 women. States such as Morelos and Quintana Roo reported a higher incidence of syphilis and a lower incidence of congenital syphilis; in contrast, states such as San Luis Potosí, Tabasco and Veracruz reported a higher incidence of congenital syphilis and a lower incidence of acquired syphilis, as shown in Fig. 5.

The incidence of neonatal death due to congenital syphilis in children under 1 year of age in Mexico increased from 0.19 cases per 100,000 newborns (5 deaths) in 2010, 0.51 cases per 100,000 newborns (12 deaths) in 2015 , and 0.88 cases per 100,000 newborns (19 deaths) in 2018. Information on other years was as follows: 2011 ( 0.39 cases and 10 deaths), 2012 (0.36 cases and 9 deaths), 2013 ( 0.28 cases and 7 deaths), 2014 (0.08 cases and 2 deaths), 2016 ( 0.35 cases and 8 deaths), and 2017 (0.49 cases and 11 deaths). Considering the total number of deaths between 2010 and 2018, the states of Jalisco (10), Baja California (9), Sonora (7) and Veracruz (6) reported the highest number of deaths; in contrast, the states of Guerrero, Hidalgo, Puebla, Quintana Roo, San Luis Potosí, Tlaxcala, Yucatán and Zacatecas did not report any neonatal deaths from congenital syphilis during the period analyzed.

\section{Discussion}

According to the latest WHO estimates, the frequency of syphilis remained constant between 2012 and 2016, with a prevalence of $0.5 \%$, in both men and women worldwide; however, in the Americas an increase from 0.7 to $0.9 \%$ was reported in both women and men [6]. The increase in syphilis has been documented among men who have sex with men and among people living with HIV in different parts of the world [9, 10]. In Mexico, an increase in the incidence of syphilis was reported among young men between 2003 and 2013, and it was hypothesized that they might be men who have sex with men as at that time, an increase in the incidence of syphilis among women as well as an increase in the incidence of congenital syphilis had not been reported [8]. With the results of the present study, we observed that the increase in the incidence of syphilis among men continues; however, we also observed an increase of more than double in the incidence of syphilis among women, as well as a great increase in the number of cases of congenital syphilis (6 times more cases).

The increase in the incidence of syphilis cases among women occurred mainly in those of reproductive age, 


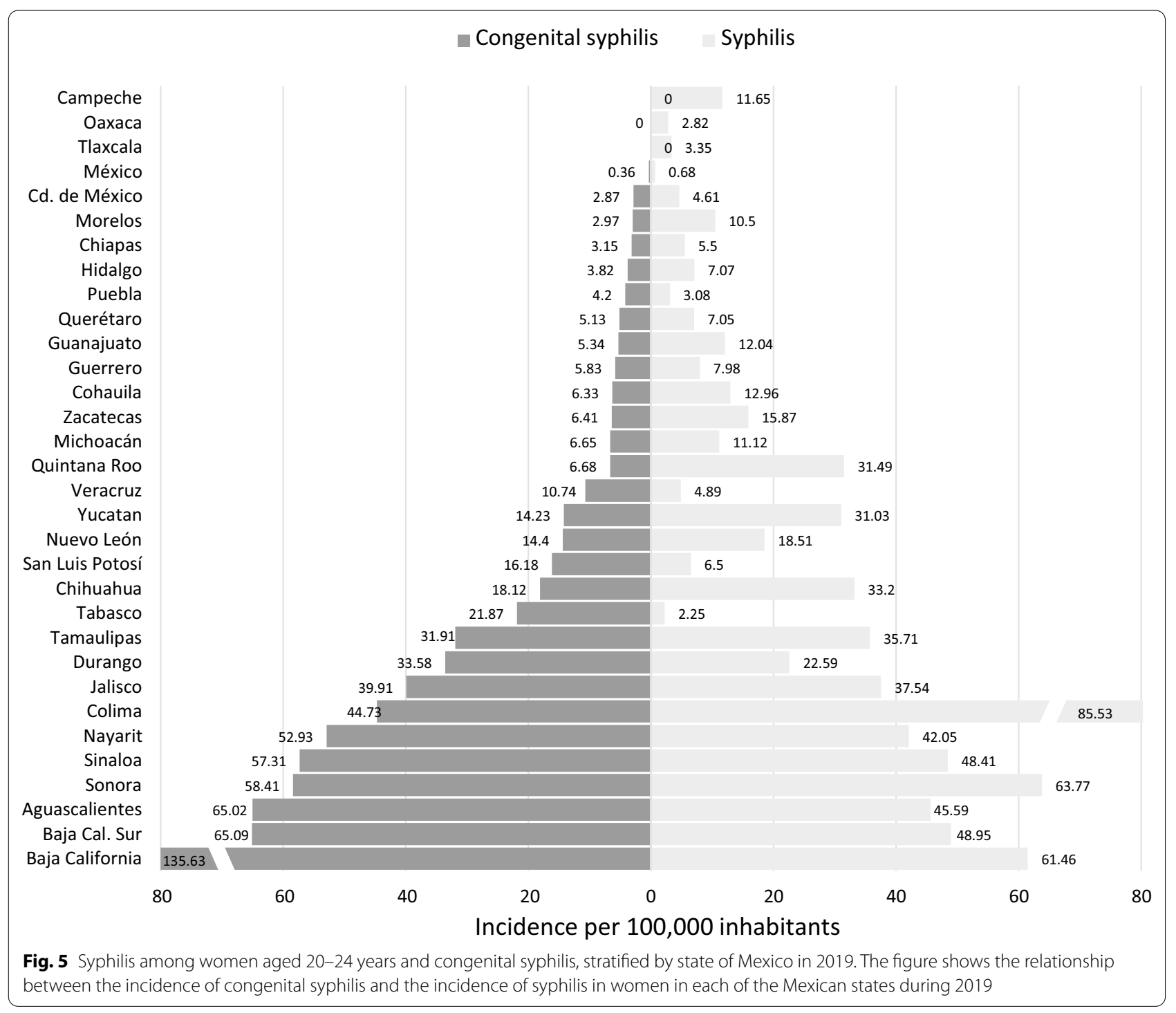

leading to an increased risk of transmission of T. pallidum during pregnancy, which results in a greater number of cases of congenital syphilis and a greater number of neonatal deaths due to congenital syphilis [11]. In 2009, the Panamerican Health Organization proposed the elimination of maternal-child transmission of syphilis and HIV, later adding Chagas disease and hepatitis B [12-14]. One of the goals is to reduce the incidence of congenital syphilis to 0.5 or less per 1000 live births $(0.005$ per 100,000 live births). In the current study, a lower rate of congenital syphilis was observed; however, in 2019, the number of cases of congenital syphilis increased from 62 cases in 2010 to 372 cases, and the number of neonatal deaths increased from 5 in 2010 to 19 in 2018.

To reach the goal of reducing the incidence of congenital syphilis, one of the main recommendations is to promote $95 \%$ coverage of syphilis screening in pregnant women and 95\% treatment [13]. However, this percentage of coverage is far from being achieved in Mexico; according to data from National Surveys (ENSANUT-2012 and ENSANUT-2018) [15, 16], only 43.6\% of teenagers reported that they were tested for syphilis during their pregnancy, which increased to $56 \%$ in 2018 , while among women aged 20-49 years, the number who were tested for syphilis increased from 39.9 to $62.5 \%$. Increased testing for syphilis during pregnancy should lead to decreased numbers of cases of congenital syphilis; however, it is unknown whether women who test positive have access to treatment [14]. Syphilis screening during pregnancy is very important, in Mexico, it is mandatory to offer a syphilis test to pregnant women; however, changes and updates to the Official Mexican Standards, 
as well as the Clinical Guidelines, must be considered [17].

Young people also showed a greater increase in the incidence of syphilis; in women, the 15-24-year-old group had the highest rates, while among men, the 20-44-yearold groups had the highest rates. In the United States, it was reported that $45 \%$ of incident STI cases are concentrated in the population aged 15-24 years [18]. Sexual activity begins during this stage, and people this age may experiment with the use of illegal drugs; in addition, low condom use has been reported in this group. It is necessary to continue with the emphasis of STI prevention programs in this age group $[19,20]$.

There is great heterogeneity in the frequency of syphilis in the states of the Mexican Republic; some states have a directly proportional correlation between the frequencies of syphilis and congenital syphilis, and other states show no apparent correlation. Further research is needed to determine the reason for these differences, which may be at the biological level (immune status, circumcision, ectopy, coinfections), at the lifestyle level (number of sexual partners, concurrent partners, partner characteristics, condom use, sexual practices and seeking medical attention), at the population level (place of residence, access to services, prevention programs, quality of care, prevalence of STIs in the locality) or at the social structure level (social class, age, sex or ethnicity) [21-23]. All these variables possibly contribute to the great variation in the incidences of syphilis and congenital syphilis in Mexico, similar to that reported for herpes simplex virus type 2 , which has a seroprevalence of $5.5 \%$ in the western region (Colima, Jalisco, Michoacán, and Nayarit) and a seroprevalence of up to $15.5 \%$ in the southwestern region (Chiapas, Guerrero and Oaxaca) [24].

A limitation of the present study includes not having more demographic, clinical or sexual behavior information. The definition of neonatal death was extended to children under 1 year of age, and information on stillbirth is lacking. In the case of women, it is unknown whether they were pregnant at the time of syphilis diagnosis; in addition, there is no information on the treatment of those who were diagnosed. There is the possibility of underreporting cases of syphilis, congenital syphilis, and neonatal deaths.

\section{Conclusions}

There is an increase in the incidence of syphilis among different population groups that is most concentrated in the young population of reproductive age, which may cause an increase in the number of cases of congenital syphilis. It is necessary to strengthen different programs, such as early detection of syphilis, treatment and follow-up of diagnosed persons and trace of contacts, to help reduce this public health problem.

\section{Abbreviations}

STI: Sexually transmitted infection; HIV: Human immunodeficiency virus; WHO: World Health Organization; 95\% Cl: 95\% Confidence intervals.

\section{Acknowledgements \\ Not applicable.}

\section{Authors' contributions}

SGC construct datasets, analyzes the graphs and write manuscript. AHO analyzes the information and reviews the manuscript. MOL reviews the manuscript. MASA construct figures, statistical analyzes, and write the manuscript.

All authors read and approved the final manuscript.

\section{Funding}

Data collection, statistical analysis, paper correction and printing were carried out with the support of CONACyT SALUD-2017-1-290201.

\section{Availability of data and materials}

Not applicable.

\section{Declarations}

\section{Ethics approval and consent to participate}

Not applicable. The study is an ecological design with public information from Health Ministery from Mexico. No administrative permissions were required to access the data, the information is freely accessible, at the electronic address of the Mexican Ministry of Health. The datasets used during the current study are available from the corresponding author on reasonable request. The people could not be identified with the information that was available.

\section{Consent for publication}

Not applicable.

\section{Competing interests}

The authors declare that they have no competing interests.

Received: 15 June 2021 Accepted: 9 September 2021

Published online: 23 September 2021

\section{References}

1. Peeling RW, Mabey D, Kamb ML, Chen XS, Radolf JD, Benzaken AS. Syphilis. Nat Rev Dis Primers. 2017:12:1-21.

2. Fonollosa A, Martinez-Indart L, Artaraz J, Martinez-Berriotxoa A, Agirrebengoa K, Garcia M, et al. Clinical manifestations and outcomes of syphilis-associated uveitis in northern Spain. Ocul Immunol Inflamm. 2016;24:147-52.

3. Hook EW 3rd. Syphilis. Lancet. 2017;389:1550-7.

4. Corti M, Palmieri O, Maronna E. Sífilis secundaria maligna, forma clínica rupioide, en una enferma VIH positive. Rara presentación de la lúes secundaria: presentación de un caso y revisión de la literatura. Rev Argen Dermatol. 2014:95:22-6.

5. Schmidt R, Carson PJ, Jansen RJ. Resurgence of syphilis in the United States: an assessment of contributing factors. Infect Dis. 2019;16(12):1178633719883282

6. Rowley J, Vander Hoorn S, Korenromp E, Low N, Unemo M, Abu-Raddad LJ, et al. Chlamydia, gonorrhoea, trichomoniasis and syphilis: global prevalence and incidence estimates, 2016. Bull World Health Organ. 2019;97:548-62.

7. Kamb M, Schwartz-Benzaken A, Karem K, Matheu J, Pérez F. Orientación para el diagnóstico de la sífilis en América Latina y el Caribe: cómo 
mejorar la adopción, interpretación y calidad del diagnóstico en diferentes entornos clínicos. Washington: OPS/OMS; 2015. p. 32.

8. Herrera-Ortiz A, Uribe-Salas FJ, Olamendi-Portugal M, García-Cisneros S, Conde-Glez CJ, Sánchez-Alemán MA. Análisis de la tendencia de síflis adquirida en México durante el periodo 2003-2013. Salud Publica Mex. 2015;57:335-42.

9. Rowley J, Vander Hoorn S, Korenromp E, Low N, Unemo M, Abu-Raddad LL, Chico RM, Smolak A, Newman L, Gottlieb S, Thwin SS, Brouteta N, Taylor MM. Chlamydia, gonorrhoea, trichomoniasis and syphilis: global prevalence and incidence estimates, 2016. Bull World Health Organ. 2019;97:548-62

10. Spiteri G, Unemo M, Mårdh O, Amato-Gauci AJ. The resurgence of syphilis in high-income countries in the 2000s: a focus on Europe. Epidemiol Infect. 2019;147: e143.

11. Galvis AE, Arrieta A. Congenital syphilis: a US perspective. Children (Basel). 2020;7:203.

12. Organización Panamericana de la Salud. Iniciativa regional para la eliminación de la transmisión maternoinfantil de VIH y de la síflis congénita en América Latina y el Caribe: documento conceptual. Montevideo: CLAP/SMR: 2009.

13. Organización Panamericana de la Salud. ETMI-PLUS: marco para la eliminación de la transmisión maternoinfantil del VIH, la síflis, la hepatitis y la enfermedad de Chagas. Julio del 2017. OPS/CHA/17-009.

14 Organización Panamericana de la Salud. Eliminación de la transmisión maternoinfantil del VIH y la síflis en las Américas. Actualización 2016. Washington, D.C.: OPS; 2017.

15. Gutiérrez JP, Rivera-Dommarco J, Shamah-Levy T, Villalpando-Hernández S, Franco A, Cuevas-Nasu L, et al. Encuesta Nacional de Salud y Nutrición 2012. Resultados Nacionales. Cuernavaca, México: Instituto Nacional de Salud Pública; 2012

16. Shamah-Levy T, Vielma-Orozco E, Heredia-Hernández O, RomeroMartínez M, Mojica-Cuevas J, Cuevas-Nasu L, et al. Encuesta Nacional de
Salud y Nutrición 2018-19: Resultados Nacionales. Cuernavaca, México: Instituto Nacional de Salud Pública; 2020.

17. Herrera-Ortiz A, López-Gatell H, García-Cisneros S, Cortés-Ortiz MA, Olamendi-Portugal M, Hegewisch-Taylor J, et al. Síflis congénita en México. Análisis de las normas nacionales e internacionales desde la perspectiva del diagnóstico de laboratorio. Gac Med Mexico. 2019;155:464-72.

18. Kreisel KM, Spicknall IH, Gargano JW, Lewis FM, Lewis RM, Markowitz LE, et al. Sexually transmitted infections among US women and men: prevalence and incidence estimates, 2018. Sex Transm Dis. 2021:48:208-14.

19. Garofoli M. Adolescent substance abuse. Prim Care. 2020;47:383-94.

20. Kann L, McManus T, Harris WA, Shanklin SL, Flint KH, Queen B, et al. Youth risk behavior surveillance-United States, 2017. MMWR Surveill Summ. 2018:67:1-114.

21 Aral SO. Determinants of STD epidemics: implications for phase appropriate intervention strategies. Sex Transm Infect. 2002;78(Suppl 1):i3-13.

22. Diez Roux AV, Aiello AE. Multilevel analysis of infectious diseases. J Infect Dis. 2005;191(Suppl 1):S25-33.

23. Toskin I, Bakunina N, Gerbase AC, Blondeel K, Stephenson R, Baggaley R, et al. A combination approach of behavioural and biomedical interventions for prevention of sexually transmitted infections. Bull World Health Organ. 2020;98(6):431-4.

24. Sanchez-Aleman MA, Del Villar-Tapia YG, Gutierrez JP, Garcia-Cisneros S, Olamendi-Portugal ML, Herrera-Ortiz A, et al. Heterogeneity of herpes simplex virus type 2 seroprevalence from a national probability survey in Mexico, 2012. Sex Transm Dis. 2018:45:111-7.

\section{Publisher's Note}

Springer Nature remains neutral with regard to jurisdictional claims in published maps and institutional affiliations.
Ready to submit your research? Choose BMC and benefit from:

- fast, convenient online submission

- thorough peer review by experienced researchers in your field

- rapid publication on acceptance

- support for research data, including large and complex data types

- gold Open Access which fosters wider collaboration and increased citations

- maximum visibility for your research: over $100 \mathrm{M}$ website views per year

At BMC, research is always in progress.

Learn more biomedcentral.com/submissions 